University of Nebraska - Lincoln

DigitalCommons@University of Nebraska - Lincoln

USDA National Wildlife Research Center - Staff Publications
U.S. Department of Agriculture: Animal and Plant Health Inspection Service

2-26-2004

\title{
Habitat associations of gopher tortoise burrows on industrial timberlands
}

Jeanne C. Jones

Brian S. Dorr

USDA/WS/NWRC, brian.s.dorr@aphis.usda.gov

Follow this and additional works at: https://digitalcommons.unl.edu/icwdm_usdanwrc

Part of the Environmental Sciences Commons

Jones, Jeanne C. and Dorr, Brian S., "Habitat associations of gopher tortoise burrows on industrial timberlands" (2004). USDA National Wildlife Research Center - Staff Publications. 502.

https://digitalcommons.unl.edu/icwdm_usdanwrc/502

This Article is brought to you for free and open access by the U.S. Department of Agriculture: Animal and Plant Health Inspection Service at DigitalCommons@University of Nebraska - Lincoln. It has been accepted for inclusion in USDA National Wildlife Research Center - Staff Publications by an authorized administrator of DigitalCommons@University of Nebraska - Lincoln. 


\title{
Habitat associations of gopher tortoise burrows on industrial timberlands
}

\begin{abstract}
Jeanne C. Jones and Brian Dorr
Abstract The western population of the gopher tortoise (Gopherus polyphemus) was listed as threatened under the Endangered Species Act in 1987 due to extensive population declines. Declines have been linked to site conversion of native pine (Pinus spp.) forests for urban development, agriculture, and commercial forest management. We conducted surveys to detect tortoise burrows on corporate timberlands in southern Mississippi and southwestern Alabama during summer 1994. We surveyed 2,759 0.5-ha strip transects on soil types of 9 different suitability categories for gopher tortoises. We found 460 active and 264 abandoned burrows on the 1,380 ha surveyed. Edaphic and vegetative conditions, such as sandy soils and total and midstory canopy coverage, influenced gopher tortoise occurrence. Logistic regression analyses revealed that active burrow occurrence was related positively to deep, sandy soils and related negatively to total canopy closure and fine loam soils with limited sand content. Abandoned burrow occurrence was related positively to increasing midstory canopy closure and selected soil types. Sandy soils and open overstory canopy that created favorable burrowing, nesting, and foraging conditions were important influences in active burrow occurrence. Vegetation management techniques, such as prescribed fire, midstory control, and intermediate forest stand thinning, are recommended on gopher tortoise conservation areas and connective corridor habitats on commercial timberlands. We theorize that restoration of longleaf pine ( $P$. palustris) forests on sandy ridges can produce desirable core habitats and dispersal corridors for gopher tortoises in landscapes dominated by intensively managed pine plantations.
\end{abstract}

Key words endangered species, gopher tortoise, Gopherus polyphemus, herpetofauna, longleaf pine ecosystem, Pinus palustris, reptiles, threatened species, tortoise

Gopher tortoises (Gopherus polyphemus) range from South Carolina through Florida and west to southeastern Louisiana. They generally inhabit upland ecosystems characterized by sandy soils, pine (Pinus spp.) forests, and abundant herbaceous understory (McRae et al. 1981). Tortoises excavate and maintain burrows that provide refuge during diel and winter dormancy periods. Burrows of adult tortoises may have several openings and exceed $4 \mathrm{~m}$ in length and $1 \mathrm{~m}$ in depth. Tortoise activity is centered around their burrows, with most foraging and egg deposition occurring near burrow openings. Although foraging distances from burrows rarely exceed $33 \mathrm{~m}$, abundance of food plants may influence daily and seasonal movement, and tortoises may expand their home range as food plant availability declines (McRae et al. 1981).

Historically, gopher tortoises inhabited the longleaf pine ( $P$. palustris) ecosystem of the Gulf Coastal Plain that was shaped by frequent lowintensity fires and typified by widely spaced overstory of uneven-aged longleaf pine and a diversity of herbaceous ground cover dominated by wiregrass (Aristida spp.) or bluestem (Andropogon spp.; Ware et al. 1993). Of the original 24 million

Address for Jeanne C. Jones: Box 9690, Department of Wildlife and Fisheries, Forest and Wildlife Research Center, Mississippi State, MS 39762, USA; jjones@cfr.msstate.edu. Address for Brian Dorr: P.O. Drawer 6099, United States Department of Agriculture, Animal Plant Health Inspection Service, National Wildlife Research Center, Mississippi State, MS 39762, USA. 


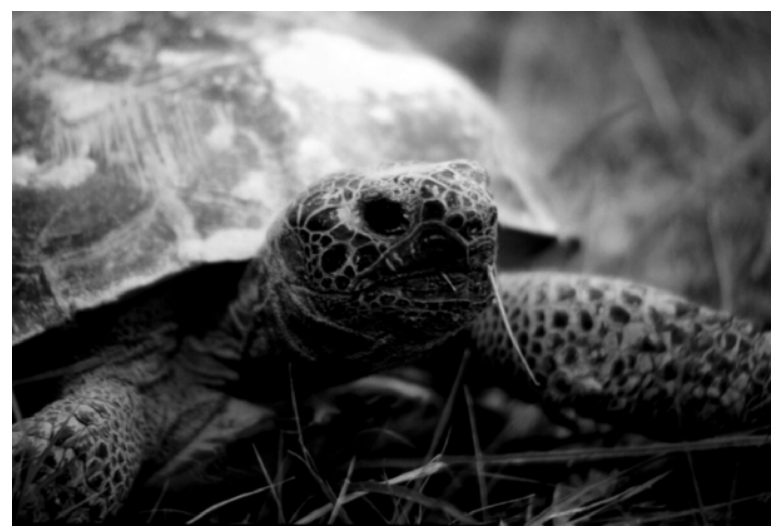

Gopher tortoises graze primarily on grasses, forbs, and legumes indigenous to lower Coastal Plain upland ecosystems of the southeastern United States. Photo by Carrie Shershanovich.

hectares of longleaf pine forests, $<1.5$ million remain today (Means 1996). An 80\% decline in gopher tortoise populations over the past 100 years has been linked to a reduction in fire incidence and the conversion of native pine forests to commercial forests, clean agriculture, or urban uses (Landers and Speake 1980, Auffenberg and Franz 1982, Diemer 1992). Today, fragmented populations are distributed within the southeastern Coastal Plain (Auffenberg and Franz 1982).

The western population of gopher tortoises was listed as threatened under the Endangered Species Act in 1987. This listing protects tortoises inhabiting lands west of the Tombigbee and Alabama river systems in southwestern Alabama, southern Mississippi, and southeastern Louisiana (United States Fish and Wildlife Service [USFWS] 1990). In the listed portion of the range, the 1990 recovery plan identified at least 18,594 ha of private lands on which gopher tortoises might occur. Much of this private land was owned or managed by timber industries (USFWS 1990).

Habitat modifications associated with commercial timber production that have been linked to tortoise population declines include site conversion to densely stocked pine plantings, ground-disruptive site preparation, and fire exclusion (Lohoefener and Lohmeier 1981; Diemer and Moler 1982; Diemer 1986, 1992). Densely planted pine plantations and lack of intermediate stand management allow gradual overstory canopy closure associated with burrow abandonment due to degradation of nesting, basking, and foraging conditions (Guyer and Hermann 1997, Aresco and Guyer 1999). Degradation and fragmentation of habitat can force tortoises to disperse to better-quality habitats and thus result in genetic isolation and mortality (Mushinsky and McCoy 1994).

Under the directives of the Endangered Species Act, industrial private landowners can develop habitat conservation plans (HCP) for federally listed populations of gopher tortoises through coordination with the USFWS (Cubbage et al. 1993). To develop effective HCPs for tortoises on commercial timberlands, data on tortoise occurrence and influential habitat conditions were needed. Our objectives in this study were to 1) report burrow densities on major soil categories and within major forest stand-soil categories and 2) determine the primary habitat conditions that influenced occurrence of active and abandoned tortoise burrows on a corporate timberland in southwestern Alabama and southern Mississippi.

\section{Study area}

The study area was a 114,390-ha land base in Washington and Mobile counties in southwestern Alabama, and Lamar, George, Pearl River, Greene, Stone, Harrison, Perry, Forrest, and Jackson counties in southern Mississippi. The area was within the range of the federally listed population of gopher tortoises; 34,120 ha of the study area exhibited soil types that could support gopher tortoises. Forests were composed primarily of even-aged loblolly $(P$. taeda), slash (P. elliottii), and longleaf pine plantations $\leq 30$ years old that were managed primarily for pulp and fiber production. Timber harvest methods included mechanized and hand-harvested selective thinning and clearcut, shelterwood, and seed-tree harvests. In clearcuts, forest regeneration was generally accomplished by planting bare-root pine seedlings at stocking rates $>1,200$ seedlings/ha. Site-preparation methods included windrowing, disking, bedding, chopping, prescribed burning, fertilization, and herbicide application. At the time of our survey, gopher tortoise burrows were protected from heavy equipment by a 7.4-m-wide protective buffer, as designated by timber company policy (J. Bullock, International Paper Company, unpublished report).

\section{Methods}

We selected sample sites within ecosystem types stratified according to soil-type categories based on suitability for gopher tortoises (USFWS 1990). We 
determined soil-type distributions on the land base using corporation soil and stand maps (International Paper Company, unpublished data). We included well-drained soil types that could potentially support tortoises in the sample population; therefore, we excluded mesic and clay-soil habitats, such as alluvial floodplains and wetlands, from the sample population. We classified selected soil types into sandy, coarse loam, and fine loam categories based on characteristics that would influence suitability for burrowing and nesting, including soil texture, sand depth, drainage, and permeability (Table 1; Landers and Speake 1980, Foth 1984, USFWS 1990). After classifying soils within the 3 major categories and verifying soil distributions on the land base, we divided the 3 major categories into 9 soil subclasses: sandy/sandy (S/S), sandy/coarse loam (S/CL), sandy/fine loam (S/FL), coarse loam/sandy (CL/S), coarse loam/coarse loam $(\mathrm{CL} / \mathrm{CL})$, coarse loam/fine loam $(\mathrm{CL} / \mathrm{FL})$, fine loam/sandy (FL/S), fine loam/coarse loam (FL/CL), and fine loam/fine loam (FL/FL). This more detailed classification was conducted due to the mixture of soil categories occurring on sample sites and was designed to classify soil categories according to dominant and co-dominant types. We considered a soil-type category to dominate if it composed $\geq 50 \%$ of the site; we considered as co-dominant a soiltype category comprising $\geq 30-49 \%$ of the site (Table 1; Foth 1984).

We overlaid forest-stand coverages supplied by industry personnel on the 9 soil subclasses to select transects within different forest types and soil subclasses. We categorized stand types according to the following characteristics: dominant pine type (loblolly, slash, or longleaf pine), forest age (0-5, 6-14, 15-25, and >25 years), and type of forest regeneration (planted or natural). We based the number of transects within each stand and soil type proportionately on the coverage of each ecosystem type on the study area. After stratification by stand and soil type, we randomly placed transects within each category given the following stipulations: adequate sample site numbers within the forest type $(n \geq 10)$, forest patch size ( $\geq 20$ ha), minimal distance between transects ( $\geq 100 \mathrm{~m}$ apart), and minimal distance of transect from forest-stand edge $(>100 \mathrm{~m})$.

We established 2,759 fixed-width transects, measuring $20 \times 250 \mathrm{~m}(0.5 \mathrm{ha})$ stratified within foresttype-soil-subclass categories (Cox et al. 1987). We marked all transect perimeters with wooden stakes and flagging. We conducted surveys from 15 May-15 September 1994 that included complete coverage of each transect by 3 surveyors. We recorded all gopher tortoise burrows occurring within transects and marked and classified them according to activity status (active or abandoned; Auffenberg and Franz 1982, Guyer and Hermann 1997). We classified burrows as active if the opening exhibited an outline similar to the profile of a tortoise carapace, a soil apron at the burrow entrance, and tortoise plastron and tracks leading into the burrow. We categorized active burrows that exhibited presence of recent tortoise activity, such as tracks or plastron slide marks, as "recently active" and measured them at the widest diameter within 3-4 cm from the opening with aluminum calipers and grouped them into 3 size classes: $\leq 20$

Table 1. Active gopher tortoise burrows and habitat variables within 9 soil categories on industrial timberlands in southern Mississippi and southwestern Alabama, summer 1994.

\begin{tabular}{|c|c|c|c|c|c|c|c|c|c|c|c|}
\hline \multirow{2}{*}{$\begin{array}{l}\text { Soil } \\
\text { category }\end{array}$} & \multirow{2}{*}{$\begin{array}{c}\text { No. } \\
\text { transects }\end{array}$} & \multicolumn{2}{|c|}{$\begin{array}{c}\text { Elevation } \\
(\mathrm{m})\end{array}$} & \multicolumn{2}{|c|}{$\begin{array}{c}\text { Canopy } \\
\text { cover }(\%)\end{array}$} & \multicolumn{2}{|c|}{$\begin{array}{l}\text { Midstory } \\
\text { cover }(\%)\end{array}$} & \multicolumn{2}{|c|}{$\begin{array}{c}\text { Herbaceous } \\
\text { cover }(\%)\end{array}$} & \multicolumn{2}{|c|}{$\begin{array}{c}\text { Active } \\
\text { burrows } \\
\text { (No./ha) }\end{array}$} \\
\hline & & $\bar{x}$ & SE & $\bar{x}$ & SE & $\bar{x}$ & $\mathrm{SE}$ & $\bar{x}$ & SE & $\bar{x}$ & SE \\
\hline $\mathrm{S} / \mathrm{S}$ & 600 & 65.9 & 0.1 & 51.7 & 1.4 & 30.8 & 1.5 & 35.2 & 1.3 & 0.62 & 0.03 \\
\hline $\mathrm{S} / \mathrm{CL}$ & 263 & 63.2 & 0.1 & 54.2 & 2.1 & 39.2 & 2.1 & 36.9 & 2.0 & 0.34 & 0.03 \\
\hline $\mathrm{S} / \mathrm{FL}$ & 149 & 54.0 & 1.7 & 50.2 & 2.5 & 35.2 & 2.4 & 39.6 & 2.6 & 0.16 & 0.02 \\
\hline $\mathrm{CL} / \mathrm{S}$ & 286 & 62.4 & 1.2 & 55.2 & 2.0 & 31.1 & 1.6 & 39.1 & 2.0 & 0.36 & 0.04 \\
\hline $\mathrm{CL} / \mathrm{CL}$ & 581 & 49.1 & 0.8 & 68.5 & 1.3 & 40.9 & 1.3 & 34.1 & 1.4 & 0.28 & 0.02 \\
\hline $\mathrm{CL} / \mathrm{FL}$ & 206 & 44.3 & 1.2 & 65.6 & 2.1 & 47.6 & 2.2 & 44.5 & 2.7 & 0.18 & 0.03 \\
\hline $\mathrm{CL} / \mathrm{S}$ & 54 & 48.5 & 2.8 & 64.3 & 4.3 & 45.2 & 4.3 & 24.2 & 4.7 & 0.22 & 0.05 \\
\hline $\mathrm{FL} / \mathrm{CL}$ & 103 & 42.9 & 17.8 & 59.8 & 2.8 & 50.4 & 3.2 & 37.0 & 3.2 & 0.10 & 0.03 \\
\hline $\mathrm{FL} / \mathrm{FL}$ & 517 & 45.2 & 0.8 & 63.3 & 1.3 & 43.6 & 1.4 & 36.9 & 1.6 & 0.30 & 0.02 \\
\hline
\end{tabular}

a Sandy/sandy (S/S) - First listed soil represents dominant soil type ( $\geq 50 \%$ of sampled site); second listed soil represents co-dominant soil type $(\geq 30 \%,<50 \%)$ of sampled site. Sandy soils are deep $(>1 \mathrm{~m})$ soils with siliceous thermic characteristics, including Alaga, Lakeland, Eustis, Nugent, and Troup. Coarse loam (CL) soils are siliceous thermic Paleudults, including Benndale, Harleston, Hiedel, McLaurin, Norfolk, Orangeburg, Poarch, Ruston, and Smithdale. Fine loam (FL) soils are fine to medium loams with siliceous thermic characteristics, including Basin, Bibb-Ponser, Bibb-Susquehanna, Boswell, Daleville, Izagora, Lynchburg, Mashulaville, Myatt, Quitman, Saucier, Smithton, and Susquehanna (International Paper Company, unpublished data; United States Natural Resource Conservation Service 2001). 
$\mathrm{cm}, 20-30 \mathrm{~cm},>30 \mathrm{~cm}$ (Mushinsky and McCoy 1994, Guyer and Hermann 1997). Burrows that exhibited no evidence of tortoise activity, eroded entrance outlines, and presence of undisturbed vegetation or soil in the burrow entrance were classified as abandoned (Guyer and Hermann 1997). We excluded burrows occupied and modified by armadillos (Dasypus novemcinctus) if burrow condition precluded a determination that a tortoise had originally occupied the burrow.

We measured edaphic and vegetation conditions within a $10 \times 20$-m quadrat on each transect midpoint on transects supporting no burrows and at each tortoise burrow on transects supporting burrows. On transects with $\geq 1$ burrows, we collected habitat data at each burrow and derived a mean of each habitat measurement for use in analysis. We measured topographic elevations with a Global Positioning System (GPS) receiver. We determined dominant soil texture and soil series classification using methods described by Foth (1984). Foreststand composition and age were determined from company records. Vegetation characteristics measured included verification of dominant pine stand type and percentage cover of plants occurring in 3 canopy categories: 1) upper canopy (woody vegetation $>6 \mathrm{~m}$ in height), 2) midstory cover (woody vegetation $>1-6 \mathrm{~m}$ in height), 3) ground cover (herbaceous and woody vegetation $\leq 1 \mathrm{~m}$ in height). We measured upper canopy coverage using a spherical densiometer at 4 cardinal directions $3.5 \mathrm{~m}$ from each quadrat center point and derived a mean coverage from the 4 densiometer readings (Hayes et al. 1981). We measured percent midstory and ground cover by a gridded ocular estimation of (10) $1-\mathrm{m}^{2}$ plots randomly selected within each quadrat (Hayes et al. 1981). We derived a fourth category, total canopy coverage, by adding the percent coverages of upper and midstory vegetation in each quadrat. This category was considered important ecologically due to the effect of midstory and upper canopy closure on sunlight penetration to the soil surface, tortoise food plants, and nesting conditions.

We used logistic regression to test the binary response variable of active or abandoned burrow presence or absence relative to categorical and continuous explanatory variables of edaphic and vegetation conditions (Myers 1990). We developed a model for abandoned and active burrow categories separately to identify habitat conditions that influenced active burrow occurrence and burrow abandonment. Explanatory variables included initially in our model were total canopy coverage (Canopy), upper canopy coverage (Upper), midstory canopy coverage (Midstory), herbaceous ground coverage (Herb), soil categories (9), and elevation (Elev). We created dummy variables to identify each soil category where $1=$ presence and $0=$ absence of a particular soil category for the transect (Affifi and Clark 1990). We used stepwise regression to identify variables that were related $(P \leq 0.05)$ to presence of active or abandoned burrows. We used stepwise variable selection to reduce collinearity among explanatory variables (Myers 1990, SAS Institute 1994). We used logistic regression in lieu of other regression and mixed models due to our sample size $(n=2,759)$, the limited range of burrows counted within each transect ( $0-4$ burrows), and the high number of transects $(n=2,289)$ that exhibited no burrows (Myers 1990). Our complete linear logistic model had the following form: Logit $(p)=a+B_{1} \quad$ (Canopy) $+B_{2}$ (Upper) $+B_{3}$ (Midstory) $+B_{4}$ (Herb) $+B_{5}$ through 14 (9 soil categories) $+B_{15}$ (Elev). Where: Logit $(p)=$ logistic probability of presence or absence of active or abandoned burrows, $a=$ intercept, and $B_{i}=$ parameter estimate. We tested the resulting model by crossvalidation methods to estimate accuracy (SAS Institute 1994).

We used Pearson correlation analysis to measure relationships between explanatory variables that exhibited collinearity (Myers 1990). Percent plant coverage data were transformed by square root prior to correlation analysis (Daniel 1990, Myers 1990, SAS Institute 1994).

\section{Results}

We surveyed 2,759 0.5 -ha transects (1,380 ha) during the study period; 1,706 were in Mississippi and 1,053 in Alabama. We found 460 active burrows on 317 (11\%) transects and 264 abandoned burrows on 214 (7.7\%) transects. Entrance widths of 274 "recently active" burrows ranged from $8.9-48.3 \mathrm{~cm}$, with $9 \%, 52 \%$, and $39 \%$, respectively, in the $\leq 20-\mathrm{cm},>20-30-\mathrm{cm}$, and $>30-\mathrm{cm}$ size classes. Most transects (96\%) with active burrows $(n=317)$ exhibited 1 to 2 active burrows. However, 17 transects (4\%) supported $\geq 3$ burrows within $100 \mathrm{~m}$ of one another. Fifteen of these sites (88\%) were located on S/S or S/CL soils, with total canopy coverage $<65 \%$ and herbaceous ground coverage $\geq 35 \%$. The exception to this condition was found 
on 2 transects in Washington County, Alabama, located on CL/FL and FL/FL soils dominated by $>35$ yearold, naturally regenerated, loblolly-longleaf pines. Total canopy coverage on these sites averaged $45 \%$ and $58 \%$. Herbaceous ground cover was $>30 \%$ coverage and was dominated by native grasses.

When summarized according to the 9 soil subclasses, mean densities of active burrows ranged from 0.10 burrows/ha on FL/CL soils to 0.62 burrows/ha on S/S soils. Soil subclasses were related to topographic elevation $(r=0.50, \mathrm{df}=2,754, P \leq$ $0.001)$, with deep ( $\geq 1 \mathrm{~m})$ sandy soils being more common at higher elevations $(\bar{x}=65.9, \mathrm{SE}=0.1 \mathrm{~m}$ above sea level) than CL/FL soils.

Forest-soil ecosystem types that exhibited limited or no evidence of recent gopher tortoise activity were characterized by planted, dense loblolly and slash pine plantations 6-20 years old located on coarse loam and fine loam soils. These sites lacked deep sands in the upper soil horizons and exhibited $>80 \%$ upper canopy coverage, $>40 \%$ midstory coverage, and $<10 \%$ herbaceous ground coverage. Mean burrow densities in these ecosystems ranged from 0-0.10 active burrows/ha. Foreststand types located on sites dominated by coarse loam or fine loam soils with sandy soil as a co-dominant soil type supported densities ranging from 0-0.30 active burrows/ha. These ecosystems were characterized by loblolly and slash pine plantations with $\leq 80 \%$ upper canopy coverage, $<30 \%$ midstory coverage, and $>20 \%$ herbaceous ground coverage.

Of the 9 forest types that supported $\geq 0.60$ active burrows/ha, 6 were located on sandy soil sites and 3 on coarse and fine loam soil sites (Table 2). Greatest densities of active burrows were recorded in loblolly and longleaf pine plantations within all age classes located on sandy soils (Table 2). Of stand types located on sandy soils, greatest active burrow densities were recorded in 0-5, 6-14, and $>25$ year-old longleaf pine stands (Table 2). Using the multiplier of 0.33 tortoises/active burrow developed by Mushinsky and McCoy (1994), we estimated a range of $0.22-0.43$ tortoises/ha in these ecosystems. These sites were typified by sandy soils $>1 \mathrm{~m}$, total canopy coverage $<65 \%$, midstory coverage $<35 \%$, and herbaceous ground coverage $>35 \%$.

Logistic regression and stepwise procedures revealed that 3 explanatory variables were related to the occurrence of active gopher tortoise burrows: soil subclass $\mathrm{S} / \mathrm{S}\left(\chi^{2}=43.0, \mathrm{df}=11, P \leq 0.001\right)$, total canopy coverage $\left(\chi^{2}=5.6, \mathrm{df}=10, P=0.018\right)$, and soil subclass $\mathrm{FL} / \mathrm{CL}\left(\chi^{2}=5.1, \mathrm{df}=9, P=0.024\right)$. The model was significant at the $P \leq 0.001\left(\chi^{2}=\right.$ 61.0, $\mathrm{df}=12$ ) level in determining the occurrence of active burrows. Within-model cross-validation correctly predicted the presence or absence of active burrows for $72.1 \%(n=1,989)$ of the observed outcomes. The reduced logistic model for active bur-

Table 2. Gopher tortoise burrow densities and habitat variables in forest types with soil categories supporting densities of $\geq 0.60$ active burrows/ha on industrial timberlands in southern Mississippi and southwestern Alabama, summer 1994.

\begin{tabular}{|c|c|c|c|c|c|c|c|c|c|c|c|c|}
\hline \multirow{2}{*}{$\begin{array}{l}\text { Forest type } \\
\text { and age class }\end{array}$} & \multirow[b]{2}{*}{ Soil categorya } & \multirow[b]{2}{*}{ No. transects } & \multicolumn{2}{|c|}{ Elevation $(\mathrm{m})$} & \multicolumn{2}{|c|}{$\begin{array}{c}\text { Canopy } \\
\text { cover }>1 \mathrm{~m}(\%)\end{array}$} & \multicolumn{2}{|c|}{$\begin{array}{c}\text { Herbaceous } \\
\text { ground cover (\%) }\end{array}$} & \multicolumn{2}{|c|}{$\begin{array}{c}\text { No. abandoned } \\
\text { burrows/ha }\end{array}$} & \multicolumn{2}{|c|}{$\begin{array}{c}\text { No. active } \\
\text { burrows/ha }\end{array}$} \\
\hline & & & $\bar{x}$ & SE & $\bar{x}$ & SE & $\bar{x}$ & SE & $\bar{x}$ & SE & $\bar{x}$ & SE \\
\hline \multicolumn{13}{|l|}{ Longleaf pine } \\
\hline $0-5 \mathrm{yr}$ & $\mathrm{S} / \mathrm{S}$ & 55 & 67.0 & 2.0 & 30.4 & 2.5 & 53.6 & 6.5 & 0.4 & 0.0 & 1.3 & 0.2 \\
\hline $6-14 \mathrm{yr}$ & $S / S$ & 55 & 63.7 & 1.3 & 61.9 & 3.2 & 42.4 & 4.5 & 0.6 & 0.1 & 1.1 & 0.3 \\
\hline $6-14 \mathrm{yr}^{\mathrm{b}}$ & $\mathrm{CL} / \mathrm{S}$ & 23 & 56.4 & 5.2 & 60.8 & 2.0 & 49.3 & 2.1 & 0.2 & 0.1 & 0.6 & 0.3 \\
\hline $15-25 \mathrm{yr}$ & $\mathrm{S} / \mathrm{S}$ & 36 & 61.3 & 2.3 & 62.0 & 5.1 & 16.1 & 4.0 & 1.2 & 0.4 & 0.7 & 0.2 \\
\hline$>25 \mathrm{yr}^{\mathrm{b}}$ & $\mathrm{S} / \mathrm{S}$ & 16 & 78.2 & 2.2 & 58.1 & 3.4 & 26.0 & 5.8 & 0.1 & 0.1 & 1.0 & 0.3 \\
\hline \multicolumn{13}{|l|}{ Loblolly pine } \\
\hline $0-5 \mathrm{yr}$ & $\mathrm{CL} / \mathrm{S}$ & 250 & 55.5 & 0.9 & 31.1 & 1.7 & 46.4 & 2.0 & 0.3 & 0.1 & 0.7 & 0.1 \\
\hline $6-14 y r$ & $\mathrm{~S} / \mathrm{CL}$ & 130 & 51.5 & 1.6 & 79.5 & 2.1 & 31.4 & 2.9 & 0.5 & 0.1 & 0.7 & 0.1 \\
\hline $15-25 \mathrm{yr}$ & $\mathrm{S} / \mathrm{FL}$ & 45 & 42.2 & 2.2 & 84.9 & 1.7 & 15.8 & 2.6 & 0.2 & 0.1 & 0.6 & 0.2 \\
\hline \multicolumn{13}{|c|}{$\begin{array}{l}\text { Naturalc loblolly- } \\
\text { longleaf pine }\end{array}$} \\
\hline$>25 \mathrm{yr}$ & $\mathrm{CL} / \mathrm{FL}$ & 34 & 32.8 & 2.0 & 74.0 & 3.8 & 37.9 & 5.8 & 0.1 & 0.0 & 0.6 & 0.2 \\
\hline
\end{tabular}


row occurrence was: Logit (active burrow presence) $=-2.0+0.8[$ soil (S/S) $]-0.0004$ (Total Canopy) -1.2 [soil (FL/CL)].

The reduced model to determine abandoned burrow presence was significant $\left(\chi^{2}=55.5, \mathrm{df}=13\right.$, $P \leq 0.001)$ and identified 4 explanatory variables that influenced the distribution of abandoned burrows: midstory percent coverage $\left(\chi^{2}=16.4\right.$, $\mathrm{df}=11$, $P \leq 0.001), \mathrm{S} / \mathrm{S}\left(\chi^{2}=20.8, \mathrm{df}=12, P \leq 0.001\right), \mathrm{CL} / \mathrm{S}$ soils $\left(\chi^{2}=6.8, \mathrm{df}=9, P=0.009\right)$, and CL/FL soils $\left(\chi^{2}=4.6\right.$, $\mathrm{df}=8, P=0.031)$. Within-model cross-validation correctly predicted the presence or absence of active burrows for $41.8 \%(n=1,154)$ of the observed outcomes. The reduced model for abandoned burrow presence was: Logit (abandoned burrow presence) $=-3.1+0.70[$ soil $(\mathrm{S} / \mathrm{S})]+0.51[$ soil $(\mathrm{CL} / \mathrm{S})]+0.01$ (midstory coverage) -0.89 [soil $(\mathrm{CL} / \mathrm{FL})]$.

Presence of the S/S soil subclass was related positively to the presence of active burrows, whereas FL/CL soil subclass and total canopy coverage were related inversely to presence of active burrows. Abandoned burrows were more common on 2 sandy soil subclasses (S/S and CL/S) and more rare in the CL/FL soil subclass; however, abandoned burrow occurrence was positively related to increasing midstory canopy coverage. Correlation analysis revealed that herbaceous ground coverage was related inversely to increases in all canopy categories $>1 \mathrm{~m}$ in height, including total canopy coverage ( $r=-0.50, \mathrm{df}=2,757, P \leq 0.001)$, upper canopy coverage $(r=-0.31, \mathrm{df}=2,755, P \leq 0.001)$, and midstory coverage $(r=-0.12, \mathrm{df}=2,755, P \leq 0.001)$. Midstory canopy coverage also was influenced by soil subclass, with fine loam and coarse loam soil subclasses supporting more shrub (Ilex spp., Myrica spp., Rbus spp., Vaccinium spp.) and tree (Acer spp., Liquidambar spp., Quercus spp., Ulmus spp.) midstory ( $r=0.50, \mathrm{df}=2,756, P=$ $0.025)$.

\section{Discussion}

We found active gopher tortoise burrows on less than $12 \%$ of our study area, and most burrows were $>20 \mathrm{~cm}$ in size. Of the 274 recently active burrows found, $9 \%$ were $\leq 20 \mathrm{~cm}$ in size. The size distribution of active burrow widths has been reported to accurately reflect the size distribution of carapace lengths and relative age-class structure of resident tortoise populations (Auffenberg and Franz 1982, Mushinsky and McCoy 1994). Thus, we believe the limited number of small burrows found on our study area indicated a low number of young tortoises. A scarcity of small burrows and low recruitment of young tortoises have been reported on public and private lands managed for timber production, development, and agriculture (Diemer 1992, Smith et al. 1997). We acknowledge that detection of small burrows is difficult due to lower persistence and visibility (Guyer and Hermann 1997, Smith et al. 1997) and that these factors may have influenced our $\leq 20$-cm burrow counts.

Distribution of active tortoise burrows on commercial timberlands was influenced by soil conditions and total canopy coverage. Greater incidence of active and abandoned burrows on sites dominated by sandy soils $>1.0 \mathrm{~m}$ in depth supports earlier findings that tortoises select sites where soil conditions are conducive to good drainage, burrow construction, and adequate forage availability (Landers and Speake 1980, Diemer 1986). Occurrence of abandoned and active tortoise burrows on all 9 soil subclasses indicated that tortoises utilized a range of well-drained soil-texture classes depending on vegetation structure. Overstory and midstory canopy closure that limited herbaceous food plant coverage and reduced quality of habitat for nesting influenced tortoise burrow occurrence and activity status. Canopy closure associated with burrow abandonment generally occurred in pine plantations with no evidence of intermediate management, such as stand thinning or prescribed burning (International Paper Company, unpublished data). This condition was observed most frequently in stands 10-20 years old when crown development of planted pine seedlings and naturally colonizing midstory caused canopy closure. For about 7 years following timber harvest and regeneration, most pine plantations exhibited open-canopy conditions and herbaceous ground cover; however, in the absence of prescribed burning, selective herbicide, or stand thinning, most 8-9-year-old plantations had begun to develop dense midstory and overstory canopies. By year 10, tree and shrub canopy closure $\geq 80 \%$ was common in most pine plantations located on fine loam and coarse loam soils. We found lesser numbers of active tortoise burrows under these conditions.

Of the forest-soil types surveyed, planted and naturally regenerated longleaf pine stands and naturally regenerated loblolly-longleaf pine stands on sandy soil sites exhibited the best habitat conditions for gopher tortoises. Naturally regenerated pine forests were typified by open, parklike stands 
of older age-class trees ( $>25$ years) that had been thinned to basal areas of $<35 \mathrm{~m}^{2} / \mathrm{ha}$, no evidence of recent mechanical soil disturbance, such as bedding or drum chopping (International Paper Company, unpublished report), and $>20 \%$ coverage of native legumes, grasses, and forbs. Our study supports the conclusions of many studies that have investigated the negative effects of canopy closure on gopher tortoise habitat quality on public and non-industrial private lands (Auffenberg and Franz 1982, Mushinsky and McCoy 1994, Guyer and Hermann 1997, Smith et al. 1997). Burrow abandonment by tortoises has been reported within 5 years following regeneration in pine plantations, due to changes in overstory structure that shaded active burrows and degraded foraging and nesting conditions (Auffenberg and Iverson 1979, Lohoefener and Lohmeier 1981, Guyer and Hermann 1997).

Mushinsky and McCoy (1994) reported that habitat fragmentation can result in genetic isolation and increased intraspecific competition. Fragmentation of desirable tortoise habitat may exist on commercial timberlands that are managed for short-rotation ( $<25$ years) pulp and fiber production because of the extent, interspersion, stand size, and stocking densities of pine plantations over large landscapes. Adequate habitats for displaced and moving tortoises may not be available adjacent to once-occupied sites if adjacent habitats are typified by closedcanopy pine plantations with limited food plant availability. Dense pine plantations of large surface coverage may serve as barriers to tortoise movement. Under these conditions, tortoises may relocate to roadsides where forage is available yet vulnerability to vehicle strikes, predation, and illegal harvest is greater (Diemer and Moler 1982, Diemer 1986).

Although increasing canopy closure was related to reduced ground cover vegetation and occurrence of active burrows, our model did not detect a significant relationship $(P \leq 0.05)$ between active burrow occurrence and percent ground cover $<1$ $\mathrm{m}$ in height. Our findings were similar to those of Aresco and Guyer (1999), who found no significant relationship between active burrows and total ground cover, although they reported that activeburrow locations exhibited a greater coverage of grasses. Aresco and Guyer (1999) attributed their findings to a low species diversity of ground cover plants, which they theorized was related to past site-preparation methods. Similar conditions may exist on commercial timberlands managed through intensive site preparation on <25-year rotations. Limited published data are available on potential short-term and residual effects of herbicide prescriptions on tortoise food plants. Research similar to deer forage studies on industrial timberlands is needed to address effects of different site-preparation methods on gopher tortoise food plants and subsequent effects on tortoise populations.

\section{Management implications}

Greater densities of tortoise burrows and positive relationships of burrows to sandy soil sites and vegetation conditions represent important information for land managers who are designing gopher tortoise surveys or habitat conservation plans. Our findings indicate that sand content and depth, elevation, and canopy conditions can be used to predict the occurrence of active gopher tortoise burrows on commercial forestlands. Additionally, total canopy coverage was less on sandy soil sites, primarily due to soil characteristics that supported less-dense vegetation and a preponderance of longleaf pine. Habitat management for tortoises on commercial timberlands can be more effective on sandier sites because of the effects of edaphic factors on plant communities and tortoise habitat use. In addition to managing tortoises in "conservation areas," we recommend that sandy soil ridges be managed as corridors to facilitate connectivity, dispersal, and genetic interchange of tortoise populations featured in conservation planning.

Edaphic conditions, soil series, and topography occurring on land bases also can be used to develop pragmatic, cost-effective surveys. Because our logistic model correctly predicted presence or absence of $72 \%$ of the active burrows based on soil and canopy conditions, we recommend designing surveys through stratification of dominant soil series and within-forest stand conditions that may support gopher tortoises. Because abandoned burrows were dispersed across more soil types, this type of stratification and prioritization may not enable detection of most abandoned burrows. We recommend measurement of vegetation conditions at each sample site and each active-burrow location to develop reliable information on localized habitatquality effects on tortoises. This effort is important due to variability of vegetation characteristics that may occur within forest stands due to land use and management and microsite conditions. 
Due to strong influences of soils and canopy closure on active-burrow occurrence, we recommend prioritization of habitat restoration and conservation planning on sandy soil ecosystems that support gopher tortoises on commercial timberlands. Because longleaf pine stands on sandy soils exhibited high-quality habitat, regeneration to longleaf pine should be considered for tortoise conservation areas. If tortoises are isolated on lands fragmented by dense pine plantations, the creation of corridors through regeneration of longleaf pine on sandy ridges that link these tortoise populations could facilitate dispersal and gene flow. Additionally, intermediate stand management, such as prescribed burning and thinning of dense pine plantations, could enhance gopher tortoise conservation on industrial forestlands. We recommend a continuation of International Paper Company policy in which a protective buffer is retained around burrows where mechanized timber harvest and site preparation is restricted or limited. In these buffers, selective removal of trees and shrubs by chain saw is recommended.

Silvicultural management that improves gopher tortoise habitat can be compatible with timber and income production on commercial forestlands. For example, control of competing midstory vegetation that enhances foraging and nesting conditions for gopher tortoises also can increase growth rates in featured pine trees (Yarrow and Yarrow 1999). Additionally, intermediate stand management, such as selective thinning and prescribed fire, that produces desirable habitat conditions for gopher tortoises also enhances habitat conditions for many upland game species that are valued for recreational use, including northern bobwhite (Colinus virginianus), white-tailed deer (Odocoileus virginianus), eastern wild turkey (Meleagris gallopavo), and cottontail rabbit (Sylvilagus floridanus) (Yarrow and Yarrow 1999). Proactive management that integrates sustainable forestry initiatives, wildlife management, and tortoise conservation can promote a positive public image for timber corporations and benefit rare species assemblages that were once common to the longleaf pine ecosystem of the lower Gulf Coastal Plains.

Acknowledgments. Special thanks are offered to 14 technicians who worked diligently despite sweltering heat, humidity, ticks, and dense "briar" thickets. We thank International Paper Timberlands Operating Company, LTD, for funding this project. Appreciation is also extended to the Forest and
Wildlife Research Center, Mississippi State University, for providing administrative and facilities support. Thanks go to R. Kaminski, B. Leopold, and D.Jackson for their reviews of this paper, which is article number WF 192, Forest and Wildlife Research Center, Mississippi State University.

\section{Literature cited}

AfFifi, A. A., AND V. Clark. 1990. Computer aided multivariate analysis. Second edition. Van Nostrand Reinhold, New York, New York, USA.

AResCo, M. J., AND C. GuYer. 1999. Burrow abandonment by gopher tortoises in slash pine plantations of the Conecuh National Forest. Journal of Wildlife Management 63:26-35.

AUfFenBERG,W.,AND R. Franz. 1982. The status and distribution of the gopher tortoise (Gopherus polyphemus). Pages 95-126 in R. B. Bury, editor. North American tortoises: conservation and ecology. United States Fish and Wildlife Service, Wildlife Research Report 12.

AUfFenbERG,W.,AND J. B. Iverson. 1979. Demography of terrestrial turtles. Pages 541-569 in M. Harless and H. Morlock editors. Turtles: perspectives and research. John Wiley and Sons, New York, New York. USA.

Cox, J., D. InKLeY, AND R. KauTZ. 1987. Ecology and habitat protection needs of gopher tortoise (Gopherus poyphemus) populations found on lands slated for large scale development in Florida. Florida Game and Freshwater Fish Commission Technical Report 4.

Cubbage, F. W., J. O'Laughlin, and C. S. Bullock, III. 1993. Forest resource policy. John Wiley and Sons, New York, New York, USA.

DANIEL, W. W. 1990. Applied nonparametric statistics. PWSKENT, Boston, Massachusetts, USA.

DiEMER, J. E. 1986. The ecology and management of the gopher tortoise in the southeastern United States. Herpetologica 42: 125-133.

Diemer, J. E. 1992. Demography of the tortoise Gopherus polyphemus in northern Florida. Journal of Herpetology 26: 281-289.

Diemer, J. E., AND P. E. Moler. 1982. Gopher tortoise response to site preparation in northern Florida. Proceedings of the Annual Conference of the Southeastern Association of Fish and Wildlife Agencies 36:634-637.

Foth, H. D. 1984. Fundamentals of soil science. John Wiley and Sons, New York, New York, USA.

GuYer, C., AND S. M. Hermann. 1997. Patterns of size and longevity of gopher tortoise (Gopherus polyphemus) burrows: implications for the longleaf pine ecosystem. Chelonian Conservation 2: 507-513.

Hayes, R. L., C. Summers, AND W. SeItZ. 1981. Estimating habitat variables. United States Fish and Wildlife Service Report 42.

LANDERS, J. L., AND D.W. SPEAKE. 1980. Management needs of sandhill reptiles in southern Georgia. Proceedings of the Annual Conference of the Southeastern Association of Fish and Wildlife Agencies 34:515-529.

LOHOEFENER, R.,AND L. LOHMEIER. 1981. Comparison of gopher tortoise (Gopherus polyphemus) habitats in young slash pine and old longleaf pine areas in southern Mississippi. Journal of Herpetology 15:239-242.

MCRAE, W.A., J. L. LANDERS, AND J.A. GARNER. 1981. Movement pat- 
terns and home range of the gopher tortoise. American Midland Naturalist 106:165-179.

Means, D. B. 1996. Longleaf pine forest, going, going... Pages 210-229 in M. B. Davis, editor. Eastern old-growth forests. Island Press, Washington, D.C., USA.

Mushinsky, H. R., AND E. D. MCCoy. 1994. Comparison of gopher tortoise populations on islands and on the mainland of Florida. Pages 39-47 in B. Bury and D. J. Germano, editors. Biology of North American tortoises. United States Fish and Wildlife Service, Washington, D.C., USA.

MYERS, R. H. 1990. Classical and modern regression with applications. PWS-KENT, Boston, Massachusetts, USA

SAS Institute. 1994. SAS Statistics user's guide. SAS Institute, Cary, North Carolina, USA.

Smith, K. R., J.A. Hurley,AND R.A. Seigel. 1997. Reproductive biology and demography of gopher tortoises (Gopherus polyphemus) from the western portion of their range. Chelonian Conservation and Biology 2:596-600.

United States Fish and Wildlife Service. 1990. Gopher tortoise (Gopherus polyphemus) recovery plan. United States Fish and Wildlife Service, Atlanta, Georgia, USA.

United States Natural Resource Conservation Service. 2001. Soil surveys for Mississippi and Alabama. United States Department of Agriculture. Available online at: http:// www.soils.usda.gov/soil_survey/pub-sur.htm (accessed August 2000 and October 2001).

WARE, S., C. Frost, AND P. D. DOERr. 1993. Southern mixed hardwood forest: the former longleaf pine forest. Pages 447-493 in W. H. Martin, S. G. Boyce, and A. C. Echternacht, editors. Biodiversity of the southeastern United States. John Wiley and Sons, New York, New York, USA.

YARROW, G. K., AND D. T. YARROW. 1999. Managing wildlife. Alabama Wildlife Federation, Montgomery, USA.

Dr. Jeanne Jones (right) is an associate professor in the Department of Wildlife and Fisheries at Mississippi State University, where she teaches courses in wildlife and plant ecology, wildlife habitat management, and restoration ecology. She has received 7 outstanding teaching awards and 2 service awards from Mississippi State University. She has authored and co-authored over 56 publications, technical reports, and book chapters on native species diversity, reptile and amphibian conservation, ecotourism, and restoration ecology. Her primary research interests include restoration of degraded ecosystems, control of invasive, nonnative species, and management strategies for conservation of sensitive plant, amphibian, bird, and reptile communities. She currently serves as President of the

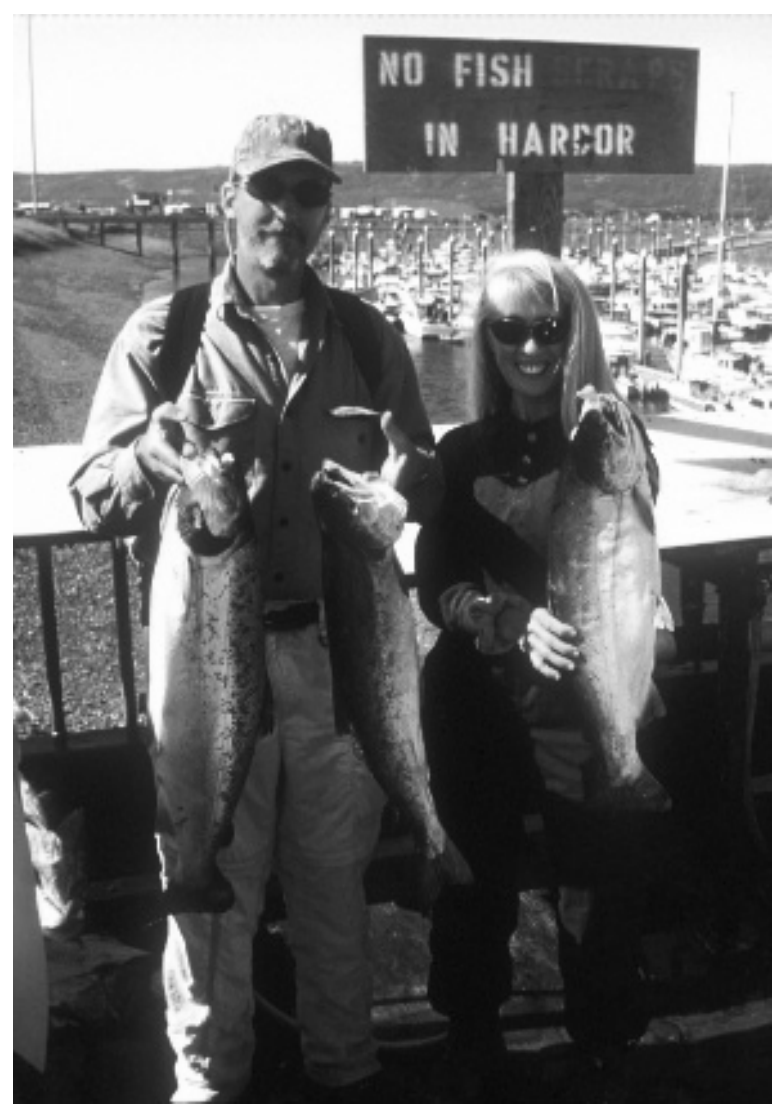

Southeastern Section of the Wildlife Society, is the Northeast Mississippi Director for the Mississippi Wildlife Federation, and is active in five other professional, honorary, and scientific organizations. Brian Dorr (left) is a wildlife biologist for United States Department of Agriculture, APHIS, Wildlife Research Center in Starkville, Mississippi where he conducts research on ecology of piscivorous waterbirds. Brian holds a B.S. degree in wildlife biology from University of Arizona and M.S. from Mississippi State University in fisheries science. He has authored and co-authored over 20 refereed or peer-reviewed publications and over 30 technical reports since 1995 . He is currently completing a doctorate of philosophy in wildlife science in the Department of Wildlife and Fisheries at Mississippi State University.

\section{Associate editor: Gates}

